\title{
OCCURRENCE OF TOXIN-PRODUCING CYANOBACTERIA BLOOMS IN A BRAZILIAN SEMIARID RESERVOIR
}

\author{
COSTA, I. A. S. ${ }^{1}$, AZEVEDO, S. M. F. O. ${ }^{2}$, SENNA, P. A. C. ${ }^{1}$, \\ BERNARDO, R. R. ${ }^{2}$, COSTA, S. M. ${ }^{2}$ and CHELLAPPA, N. T. ${ }^{3}$ \\ ${ }^{1}$ Universidade Federal de São Carlos, Departamento de Ecologia e Biologia Evolutiva, São Carlos, SP, Brazil \\ ${ }^{2}$ Universidade Federal do Rio de Janeiro, Instituto de Biofísica Carlos Chagas Filho, \\ Centro de Ciências da Saúde, Rio de Janeiro, RJ, Brazil \\ ${ }^{3}$ Universidade Federal do Rio Grande do Norte, Departamento de Oceanografia e Limnologia, Natal, RN, Brazil \\ Correspondence to: Ivaneide Alves Soares Costa, Universidade Federal do Rio Grande do Norte, \\ Departamento de Microbiologia e Parasitologia, CB, Laboratório de Ecologia e Toxicologia de Microrganismos Aquáticos, \\ Campus Universitário, Lagoa Nova, CEP 59072-970 Natal, RN, Brazil, e-mail: iasoares@uol.com.br
}

Received November 24, 2003 - Accepted March 9, 2004 - Distributed February 28, 2006

(With 2 figures)

\begin{abstract}
We report the occurrence of cyanobacterial blooms and the presence of cyanotoxins in water samples from the Armando Ribeiro Gonçalves reservoir $\left(06^{\circ} 08^{\prime} \mathrm{S}\right.$ and $\left.37^{\circ} 07^{\prime} \mathrm{W}\right)$, located in the state of Rio Grande do Norte, in the semiarid region of northeastern Brazil. The cyanobacterial species were identified and quantified during the rainy and dry seasons in the year 2000. Cyanotoxins such as microcystins, saxitoxins and cylindrospermopsins were analyzed and quantified using HPLC and ELISA methods. The mixed toxic blooms of Cylindrospermopsis raciborskii, Microcystis spp (M. panniformis, M. protocystis, M. novacekii) and Aphanizomenon spp (Aphanizomenon gracile, A. cf. manguinii, A. cf. issastschenkoi) were persistent and represented $90-100 \%$ of the total phytoplankton species. Toxic cyanobacterial blooms from the Armando Ribeiro Gonçalves reservoir were analyzed and found to have three phases in relation to the annual cycle. During the rainy season, an intense toxic bloom of Cylindrospermopsis raciborskii was recorded along with saxitoxins $\left(3.14 \mu \mathrm{g} . \mathrm{L}^{-1}\right)$. During the transition period, between the rainy and dry seasons, different species of Microscytis occurred and microcystin as high as $8.8 \mu \mathrm{g} . \mathrm{L}^{-1}$ was recorded. In the dry season, co-dominance of Cylindrospermopsis raciborskii, Microcystis spp and Aphanizomenon spp occurred and the concentrations of saxitoxin remained very low. Our results indicate the presence of microcystins $\left(8.8 \mu \mathrm{g} . \mathrm{L}^{-1}\right)$ and saxitoxins $\left(3.14 \mu \mathrm{g} . \mathrm{L}^{-1}\right)$ into the crude water, with increasing concentrations from the second fortnight of April to late May 2000. The occurrence of toxic blooms in this reservoir points to a permanent risk of cyanotoxins in supply waters, indicating the need for the implementation of bloom control measures to improve the water quality. Exposure of the local population to cyanotoxins through their potential accumulation in fish muscle must also be considered.
\end{abstract}

Keywords: reservoir, semiarid, cyanobacteria, microcystin, saxitoxin.

\section{RESUMO}

\section{Ocorrência de florações tóxicas de cianobactérias em um reservatório no semi-árido brasileiro}

Nós relatamos a ocorrência de florescimentos de cianobactérias e a presença de cianotoxinas em amostras de água do reservatório Armando Ribeiro Gonçalves ( $06^{\circ} 08^{\prime}$ S; $37^{\circ} 07^{\prime} \mathrm{W}$ ) situado no Estado do Rio Grande do Norte, na região semi-árida do Brasil. Cianobactérias foram identificadas e quantificadas nos períodos seco e chuvoso do ano 2000. Cianotoxinas tais como, microcistinas, saxitoxinas e cilindrospermopsinas foram quantificadas por HPLC e ELISA. Florescimentos tóxicos mistos de Cylindrospermopsis raciborskii, Microcystis spp (M. panniformis, M. protocystis, M. novacekii) e Aphanizomenon ssp (Aphanizomenon gracile, A. cf. manguinii, A. cf. issastschenkoi) foram persistentes e representaram 90-100\% da 
comunidade fitoplanctônica ao longo do período estudado. No período de chuvas, florescimentos tóxicos de Cylindrospermopsis raciborskii coincidiram com maiores valores de saxitoxinas $\left(3,14 \mu \mathrm{g} . \mathrm{L}^{-1}\right)$. Entre o período de chuva e estiagem, ocorreram florescimentos tóxicos de Microcytis spp, excedendo o valor mínimo aceitável para consumo humano $\left(8,8 \mu \mathrm{g} \cdot \mathrm{L}^{-1}\right)$. Na estiagem, baixas concentrações de saxitoxinas foram detectadas em florescimentos menos intensos com co-dominância de Cylindrospermopsis raciborskii, Microcystis spp e Aphanizomenon spp. Nossos resultados revelaram a presença de microcistinas $\left(8,8 \mu \mathrm{g} . \mathrm{L}^{-1}\right)$ e saxitoxinas $\left(3,14 \mu \mathrm{g} . \mathrm{L}^{-1}\right)$ na água bruta, a partir da segunda quinzena de abril até o final de maio de 2000. A ocorrência de blooms tóxicos de cianobactérias no reservatório em estudo aponta um risco permanente de cianotoxinas em águas de abastecimento e indica a necessidade da implementação de medidas de controle das florações, visando à melhoria da qualidade da água. A exposição das populações locais às cianotoxinas, pela sua potencial acumulação em musculatura de peixes, também deve ser considerada.

Palavras-chave: reservatório, semi-árido, cianobactéria, microcistina, saxitoxina.

\section{INTRODUCTION}

Eutrophication is the result of uncontrolled human population growth and the discharge of urban, industrial and agriculture effluents into the aquatic ecosystems of several countries, including Brazil (Tundisi \& Matsumura-Tundisi, 1992). This represents a primary problem for water management all over the world, especially in dry regions, since one of the major consequences of eutrophication is the appearance of cyanobacterial blooms (Carmichael, 2001; Falconer, 2001; Azevedo et al., 2002).

Cyanobacterial blooms in freshwater usually comprise both toxin and non-toxin producing species (Baker and Humpage, 1994). The main toxin producing cyanobacteria genera include Anabaena, Aphanizomenon, Microcystis, Planktothrix, Lyngbya and Cylindrospermopsis (Chorus and Bartran, 1999). Cyanotoxins (hepatotoxins and neurotoxins) are responsible for the intoxication of wild and domestic animals and the contamination of drinking water, also inducing fish mortality and eliminating other aquatic biota (Carmichael 2001; Falconer 2001; Sivonen \& Jones, 1999).

In Brazil, toxic blooms of cyanobacteria have been reported in an estuary (Yunes et al., 1996), in coastal lagoons (Porfirio et al., 1999; Azevedo 1996; 1998; Azevedo et al., 1994; Magalhães et al., 2001; Lagos et al., 1999) and in reservoirs (Teixeira et al., 1993; Molica et al., 2002; Bouvy et al., 1999; Chellappa et al., 2000; Costa et al., 2001a; 2001b). Human deaths occurred through the "Caruaru Syndrome", attracting worldwide attention when 52 patients died from cyanobacterial hepatotoxins after undergoing renal dialysis (Jochimsen et al., 1998). Teixeira et al. (1993) showed a strong correlation between cyanobacterial blooms in the Itaparica reservoir (Bahia) and the death of 88 people, among 200 intoxicated after drinking water from the reservoir between March and April 1988.

In the state of Rio Grande do Norte (northeastern Brazil), cyanobacterial dominance in eutrophic freshwater systems was studied extensively over the last decade (Chellappa, 1990; Chellappa et al., 1996; Costa et al., 1998; Costa et al., 2001) and the need for cyanotoxin analysis became apparent from the findings of fish mortality associated with the toxic blooms of Microcystis aeruginosa (Chellappa et al., 2000).

The present study was undertaken at the Armando Ribeiro Gonçalves reservoir, the second largest reservoir in northeastern Brazil $\left(2.4 \times 10^{9} \mathrm{~m}^{3}\right)$, which supplies water to 400 thousand inhabitants. Intensive use of fertilizers, as well as shrimp and fish farming, take place in the hydrographic basin of this manmade reservoir, leading to high concentrations of phosphorus and nitrogen which result in water eutrophication. The low annual rainfall, characteristic of regions with high evaporation rates, also contributes to concentrate mineral salts and inorganic nutrients in the water (NaselliFlores, 1999). Several other factors such as extended solar radiation with low amplitude of annual and daily variation, high evaporation rates and high water residence period, promotes increasing growth of cyanobacterial species (Costa, 
1999). The reservoir shows a steadily growing predominance of potentially toxic cyanobacteria such as Microcystis spp, Cylindrospermopsis raciborskii, Aphanizomenon spp, Raphidiopsis and Planktothrix (Costa, 1999).

The purpose of this work is to report the occurrence of cyanobacteria blooms and their toxins in the annual cycle. Potential health risks to humans drinking the reservoir's water are also discussed.

\section{MATERIAL AND METHODS}

\section{Sample collection and phytoplankton analysis}

Samples were collected from the Armando Ribeiro Gonçalves reservoir $(n=9)$ and in the Pataxó Channel $(\mathrm{PC})(\mathrm{n}=4)$, which carries water from the reservoir to the water treatment station $(n=4)$. The samples from these two sampling points are referred to as "raw water samples". A third sampling point was set up at the outlet of the treatment station, which is referred to as "treated water". During 2000, fortnightly samples were taken in the rainy season (April-May), in the period of transition from the rainy to the dry season (July) and in the dry season (November-December). For qualitative analyses of the phytoplankton, samples were collected by vertical towing with a $20 \mu \mathrm{m}$ mesh size net and preserved in $4 \%$ formaldehyde. For phytoplankton counting, water samples were collected with a Van Dorn bottle along vertical profiles which were further pooled and preserved with Lugol solution. Phytoplankton analyses were performed using an inverted microscope, according to Lund et al. 1958. The classification system used was that of Komárek \& Anagnostidis (1989, 1995, 1998).

Cyanotoxin analyses (microcystin, saxitoxin and cylindrospermopsin) were carried out on the seston samples, which were filtered through Whatman GF/C glass fiber filters and frozen at $-20^{\circ} \mathrm{C}$. The cyanotoxins in these samples were analyzed by the High Efficiency Liquid Chromatography technique (HPLC- Shimadzu SPD-M10A). The samples of treated water were also analyzed for microcystin by immunoassay, using ELISA Microcystin Plate Kit (ENVIROLOGIX INC.).

\section{Extraction and quantification of microcystin (MYCT)}

Microcystin extraction of the seston samples was performed using a slightly modified version of Krishnamurthy et al. method (1986). The cell content was extracted three times with butanol: water $(5: 20: 75 \mathrm{v} / \mathrm{v})$ and cell debris was removed by centrifugation. The supernatant was evaporated to $30 \%$ of its initial volume and the remaining extract was filtered though a C-18 cartridge (Bond Elut C-18 Varian). The samples were eluted from the cartridge with $20 \mathrm{~mL}$ of a solution of deionized water, $20 \%$ methanol and $100 \%$ methanol, respectively. The $100 \%$ methanol fraction was evaporated to dryness, resolubilized in $1 \mathrm{~mL}$ methanol $50 \%$ and filtered through nylon filters $(0.45 \mu \mathrm{m})$. Toxins were separated by HPLC. The HPLC system was equipped with a C-18 reversed phase column $(250 \mathrm{~mm} \times 10 \mathrm{~mm}, 5 \mu \mathrm{m})$. The analysis was carried out under isocratic conditions with a mobile phase of $20 \mathrm{mM}$ ammonium acetate, $\mathrm{pH} \mathrm{5}$, and acetonitrile (7:3) for $90 \mathrm{~min}$, followed by a gradient of 30-50\% acetonitrile in water for $50 \mathrm{~min}$. The volume injected was $100 \mu \mathrm{L}$, with UV detection at $238 \mathrm{~nm}$ and a flow rate of $4.0 \mathrm{~mL} \cdot \mathrm{min}^{-1}$. The peaks obtained in the chromatograms were analyzed and compared to the absorption spectrum with the Microcystin-LR standard.

\section{Extraction and quantification of saxitoxin}

The saxitoxins (saxitoxin-STX, GonyautoxinsGTX and C-toxins) were analyzed by HPLC using the preoxidation technique described by Lawrence et al. (1991, 1995, 1996) and Lawrence \& Ménard (1991), adapted to cyanobacterial cell extraction. Toxins were extracted from the seston for $1 \mathrm{~h}$ in a shaker containing $0.5 \mathrm{M}$ acetic acid. The supernatant was evaporated and resuspended in $1 \mathrm{~mL} \mathrm{5 \%}$ acetic acid. The reaction with peroxide was done in $100 \mu \mathrm{L}$ of the extract by adding $250 \mu \mathrm{L}$ of $\mathrm{NaOH} 1 \mathrm{M}$ followed by $25 \mu \mathrm{L}$ of $5 \% \mathrm{H}_{2} \mathrm{O}_{2}$. The solution was stirred and allowed to react for $10 \mathrm{~min}$ at room temperature. Then, $20 \mu \mathrm{L}$ of acetic acid was added to the solution, which was analyzed by HPLC. The reaction with periodate was run with a solution prepared with $0.03 \mathrm{M}$ periodic acid, $0.3 \mathrm{M}$ ammonium phormiate and $0.3 \mathrm{M} \mathrm{Na}_{2} \mathrm{HPO}_{4}$ $(1: 1: 1 \mathrm{v} / \mathrm{v})$. The $\mathrm{pH}$ was adjusted to 8.2 with $\mathrm{NaOH}$ $0.2 \mathrm{M} .500 \mu \mathrm{L}$ of this solution were added to $100 \mu \mathrm{L}$ of the extract, then stirred and allowed to react for 
$10 \mathrm{~min}$ at room temperature. Finally, $10 \mu \mathrm{L}$ of acetic acid was added and the samples were analyzed by HPLC.

The analytical equipment included a pump (LC 10 AT vP), a control (SCL-10 ${ }^{\mathrm{A}} \mathrm{VP}$ ) and an injector with $20 \mu \mathrm{L}$ Loop. A fluorescence detector (RT-10 A XL) with $330 \mathrm{~nm}$ excitation and $400 \mathrm{~nm}$ emission wavelengths was used to monitor the effluent. An LC- 18 column $(15 \mathrm{~cm} \times 4.6 \mathrm{~mm}, 5 \mu \mathrm{m})$ with partition level was used. The mobile phase had an acetonitrile gradient: $0.1 \mathrm{M}$ ammonium phormiate $(\mathrm{v} / \mathrm{v})$, adjusted to $\mathrm{pH} 6.0$, varying from $0-1 \%$ in the first 15 minutes and $1-4 \%$ in the last seven minutes. The flow rate was $1 \mathrm{~mL} \cdot \mathrm{min}^{-1}$.

\section{Extraction and quantification of cylindrospermopsins (CYL)}

The cylindrospermopsin analysis was done according to Harada et al. (1994) and Hawkins et al. (1997). The extraction was obtained by adding 5\% acetic acid to the samples while stirring for $1 \mathrm{~h}$, followed by centrifugation for $10 \mathrm{~min}$ at $4000 \mathrm{~g}$, followed by chromatographic analysis using an Allsphere ODS- $2 \mu \mathrm{m}, 250 \times 4.6 \mathrm{~mm}$ internal diameter column (Altech) and detection at $262 \mathrm{~nm}$. The retention times and UV spectrum (200-300 nm) of the major peaks were compared with cylindrospermopsin standard kindly provided by Dr. Assaf Sukenik (Kinneret Institute, Haifa, Israel). A linear gradient was used from 0 to $5 \%$ methanol in deionized water for $10 \mathrm{~min}$, followed by isocratic conditions of $5 \%$ methanol for another
$10 \mathrm{~min}$. The samples displaying similar peaks were coeluted with the standard and reanalyzed to confirm the presence of the toxin.

\section{RESULTS AND DISCUSSION}

This paper work reports on the presence of high density potentially toxic cyanobacterial cells, and the presence of microcystins and saxitoxins in raw water seston samples from the Armando Ribeiro Gonçalves reservoir, the Pataxó channel, and treated water distributed through this system.

The phytoplankton community of the Armando Ribeiro Gonçalves reservoir presented a cyanobacterial predominance of $90-100 \%$ of the total phytoplankton density in the raw water in 2000. Mixed blooms of cyanobacteria comprised almost exclusively Microcystis spp (Microcystis sp, M. protocystis, M. panniformis and $M$. novacekii), Cylindrospermopsis raciborskii and Aphanizomenon spp (Aphanizomenon gracile, Aphanizomenon cf. manguinii, Aphanizomenon cf. issastschenkoi), whose predominance alternated during the period under study (Table 1). The total cyanobacterial density in the raw water collected from the Armando Ribeiro Gonçalves reservoir varied from 3 to $6 \log$.cel $/ \mathrm{mL}$, corresponding to $9.08 \times 10^{4}$ and $8.2 \times 10^{5}$ cells $/ \mathrm{mL}$ during the period in question (Fig. 1).

Our results revealed the presence of microcystins and saxitoxin. However, it was not possible to confirm the occurrence of

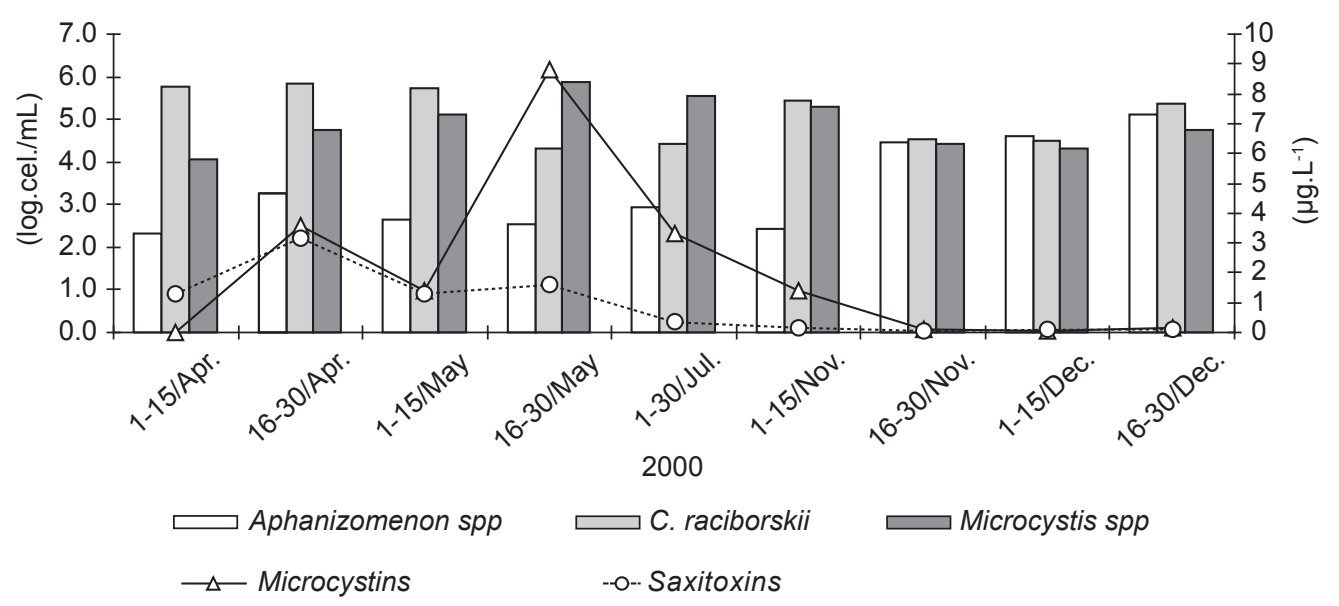

Fig. 1 - Cyanobacterial density (log.cells. $\left.\mathrm{mL}^{-1}\right)$, and microcystin and saxitoxin concentrations $\left(\mu \mathrm{g} . \mathrm{L}^{-1}\right)$ in the reservoir during the period of this study. 
TABLE 1

Predominant and subdominant cyanobacteria in the plankton samples from the Armando Ribeiro Gonçalves reservoir. Predominance was assigned arbitrarily to one or more species that were estimated to constitute $>50 \%$ of the total phytoplankton density.

\begin{tabular}{|c|c|c|}
\hline \multirow[t]{2}{*}{ (1-15 April 2000) } & Cylindrospermopsis raciborskii & • \\
\hline & Microcystis spp & 0 \\
\hline \multirow[t]{2}{*}{ (16/30 April 2000) } & Cylindrospermopsis raciborskii & - \\
\hline & Microcystis spp & 0 \\
\hline \multirow[t]{2}{*}{ (1-15 May 2000) } & Cylindrospermopsis raciborskii & - \\
\hline & Microcystis spp & 0 \\
\hline \multirow[t]{2}{*}{$(16 / 30 / \mathrm{May} / 2000)$} & Microcystis spp & $\bullet$ \\
\hline & Cylindrospermopsis raciborskii & 0 \\
\hline \multirow[t]{2}{*}{ (July 2000) } & Microcystis spp & $\bullet$ \\
\hline & Cylindrospermopsis raciborskii & 0 \\
\hline \multirow[t]{2}{*}{ (1-15 November 2000) } & Aphanizomenon spp & $\bullet$ \\
\hline & Cylindrospermopsis raciborskii & 0 \\
\hline \multirow{2}{*}{$\begin{array}{l}\text { (16/30 November } \\
2000)\end{array}$} & Cylindrospermopsis raciborskii & $\bullet$ \\
\hline & Aphanizomenon spp & 0 \\
\hline \multirow[t]{2}{*}{ (1-15 December 2000) } & Cylindrospermopsis raciborskii & $\bullet$ \\
\hline & Aphanizomenon spp & 0 \\
\hline \multirow[t]{2}{*}{ (16/30 December 2000) } & Cylindrospermopsis raciborskii & $\bullet$ \\
\hline & Aphanizomenon spp & 0 \\
\hline
\end{tabular}

- predominant; and $\bigcirc$ subdominant.

cylindrospermopsin in any of the analyzed samples. Maximum values of $3.14 \mu \mathrm{g} . \mathrm{L}^{-1}$ of saxitoxin and $8.8 \mu \mathrm{g} . \mathrm{L}^{-1}$ of microcystin were found in the seston samples of raw water from the Armando Ribeiro Gonçalves reservoir. The highest concentrations of saxitoxins were found when Cylindrospermopsis raciborskii occurred in the highest densities during the rainy season (April/May). Blooms of Microcystis spp and microcystins were also detected in this period, lasting until July (Fig. 1). Type $\mathrm{C} 1$ and $\mathrm{C} 2$ saxitoxins were the most common, corresponding to $30-50 \%$ of all the saxitoxins found in our analyses, followed by GTX, B1 and STX (data not shown).

Total cyanobacteria density averaged $4 \log . \mathrm{cel} / \mathrm{mL}$ (between $2.2 \times 10^{4}$ and $6.2 \times 10^{4}$ cells $/ \mathrm{mL}$ ) in both the Pataxó Channel raw water and in the treated water. However, the microcystin and saxitoxin concentrations were lower than the recommended levels for drinking water (Fig. 2).

Eutrophication of freshwater environments frequently stimulates the blooms of both toxic and nontoxic cyanobacteria. The toxic effect of Microcystis, Cylindrospermopsis and Anabaena has already been studied in both natural and unialgal cultures (Falconer, 2001; Sivonen \& Jones, 1999). The abundance and persistent predominance of cyanobacteria species is closely linked to the high levels of eutrophication in the reservoir studied (Costa, 1996, 1999). In this study, the reservoir presented alkaline $\mathrm{pH}$ (8-9), low transparency (0.8-1.5 m), temperature between $27^{\circ} \mathrm{C}$ and $29^{\circ} \mathrm{C}$, $\mathrm{N}$-nitrate $\left(64.4 \mu \mathrm{g} . \mathrm{L}^{-1}\right)$, N-ammonia $\left(185.4 \mu \mathrm{g} . \mathrm{L}^{-1}\right)$, Total nitrogen $\left(1150.9 \mu \mathrm{g} . \mathrm{L}^{-1}\right)$, Total phosphorus (41.5 $\left.\mu \mathrm{g} . \mathrm{L}^{-1}\right)$, and orthophosphate $\left(15.123 \mu \mathrm{g} . \mathrm{L}^{-1}\right)$. Other reservoirs located in Brazil's semiarid regions have also shown frequent blooms of cyanobacteria, such as Microcystis, Aphanizomenon and Anabaena mixed with Cylindrospermopsis raciborski, which form high biomass (with 90-100\% predominance) from November to April in most of these environments (Bouvy et al., 1999; Bouvy et al., 2000; Huszar et al., 2000).

Cyanobacteria density during the period of this study exceeded the levels for drinking water 


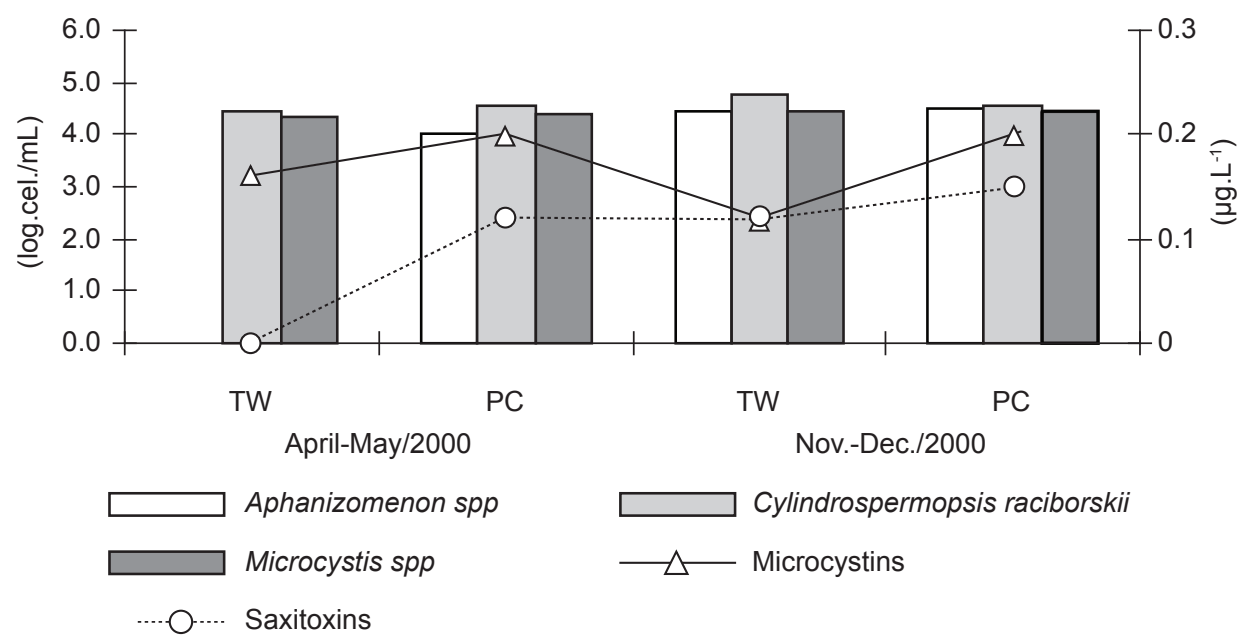

Fig. 2 - Cyanobacterial density (log.cells. $\left.\mathrm{mL}^{-1}\right)$, and microcystin and saxitoxin concentrations $\left(\mu \mathrm{g} . \mathrm{L}^{-1}\right)$ in the treated water (TW) and in Pataxó Channel (PC) in the period of this study.

$\left(<2 \times 10^{3}\right.$ cells $\left./ \mathrm{mL}\right)$ recommended by the WHO (Chorus \& Bartram, 1999), and also the limit set by the Brazilian Health Ministry $\left(20 \times 10^{3}\right.$ cell $\left./ \mathrm{mL}\right)$. The presence of numerous $C$. raciborskii and Microcystis spp cells in the treated water indicates serious deficiencies in the filtering system of the water treatment station.

The present study reveals that the highest concentrations of saxitoxin and microcystins appeared during the same period as the blooms of Cylindrospermopsis raciborskii and Microcystis spp, indicating the predominance of potentially toxin-producing species in the reservoir. The production of saxitoxin, microcystin and cylindrospermopsin has been demonstrated from both natural and cultured populations of cyanobacteria in many regions of the world, including Brazil (Falconer, 2001; Jochimsen et al., 1998; Azevedo et al., 1994).

In this study we observed three distinct periods of predominance of cyanobacteria species, types of toxin and toxin concentrations. The rainy season was marked by the overwhelming predominance of Cylindrospermopsis raciborskii with high levels of saxitoxin, followed by Microcystis spp in the transition period between the rainy and dry seasons, and finally the coexistence of Aphanizomenon spp, Cylindrospermopsis raciborskii and Microcystis $s p p$ with equivalent densities in the dry season. The maximum microcystin concentration $\left(8.8 \mu \mathrm{g} . \mathrm{L}^{-1}\right)$ was detected in the second half of May 2000, when Microcystis spp predominated with $90 \%$ of the phytoplankton density, and a concomitant reduction of saxitoxins. In July 2000, which represents the transition period, blooming of Microcystis spp was less intense and the level of microcystin was lower. In November (dry season) the phytoplankton was dominated by three coexisting dominating species of cyanobacteria, Cylindrospermopsis raciborskii, Microcystis spp and Aphanizomenon spp, while microcystin and saxitoxin concentrations were very low.

C. raciborskii blooms, associated with the presence of high saxitoxin concentrations, suggest the production of saxitoxins by this species, as already demonstrated in other freshwater environments in Brazil (Lagos et al., 1999 and Molica et al., 2002). However, in future researches, it will be necessary to confirm the origin of this toxin by means of saxitoxin analyses on monospecific cultures isolated from the sites under study.

The toxicological studies of Fitzgerald et al. (1999) suggested $3 \mu \mathrm{g} . \mathrm{L}^{-1}$ as a limit of saxitoxins for human consumption, based on $60 \mathrm{Kg}$ weight of an individual and a daily water consumption of $2 \mathrm{~L}$. This limit has already been adopted as recommended in the Brazilian Health Ministry's new resolution (M/S 1.469 of 29/12/2000) in terms of water quality for human consumption. The new 
resolution also establishes a maximum acceptable level of microcystin of $1 \mu \mathrm{g} . \mathrm{L}^{-1}$ in drinking water.

Our results revealed peaks as high as $8.8 \mu \mathrm{g} . \mathrm{L}^{-1}$ and $0.16 \mu \mathrm{g} . \mathrm{L}^{-1}$ of microcystins in raw and treated water, respectively. This demonstrates that the local water treatment is quite efficient in removing toxins from the water. However, the occurrence of $8.8 \mu \mathrm{g} . \mathrm{L}^{-1}$ in raw water exposes to high doses of these toxins at least part of the local population that uses untreated water directly from the Pataxó Channel. This situation should be considered a serious public health threat, since prolonged exposure to microcystins can lead to a higher incidence of hepatic cancer (Chorus \& Bartran, 1999; Azevedo, 1998). Exposure of the local population through accumulation of microtoxins in fish musculature must also be considered (Magalhães et al., 2001).

The presence of saxitoxins in the reservoir water during this study, as in other reservoirs in the states of Rio Grande do Norte (Costa et al., 2003a, 2003b) and Pernambuco (Molica et al., 2002), should be taken as a warning that saxitoxins may be more widely distributed in freshwater than we were aware of, particularly in northeastern Brazil.

Based on our results, we were unable to establish a correlation between cyanobacteria densities and cyanotoxin concentration, which would have enabled us to identify the seasons with the highest and lowest risk of toxin exposure. Nevertheless, we found fewer cyanobacterial cells in the running waters of the Pataxó Channel, suggesting that the use of an adequate management technique involving physical mixing processes at the water collection points of the treatment stations in the Armando Ribeiro Gonçalves reservoir could significantly reduce the number of cyanobacteria cells.

The occurrence of toxic cyanobacteria blooms recorded in this and other studies (Costa et al., 2003a, 2003b) points to the permanent risk of cyanotoxins in supply waters, not only in the Armando Ribeiro Gonçalves reservoir but also in other reservoirs in the state of Rio Grande do Norte. Therefore, there is an urgent need to regularly monitor these systems in order to advise the population, and to prevent and control toxic cyanobacterial blooms. Moreover, further investigations are recommended into cyanobacteria and cyanotoxin density in Rio Grande do Norte's other rivers and reservoirs.
Acknowledgments - The Brazilian Government, through CNPq (National Research Council), awarded I.A.S.C. with a doctoral grant. We are also indebted to Dr. Renata Panosso for improving the English text and to Beatrice Allain for proofreading it.

\section{REFERENCES}

AZEVEDO, S. M. F. O., 1998, Toxinas de cianobactérias: Causas e consequiências para a saúde pública. Medicina on line, 3(1): 1-19.

AZEVEDO, S. M. F. O., CARMICHAEL, W. W., JOCHIMSEN, E. M., RINEHART, K. L., LAU, S., SHAW, G. R. \& EAGLESHAM, G. K., 2002, Humam intoxication by microcystins during renal dialysis treatment in Caruaru - Brazil. Toxicology, 1-7. (In Press).

AZEVEDO, S. M. F. O., EVANS, W. R., CARMICHAEL, W. W. \& NAMIKOSHI, M., 1994, First Report of Microcystis from a Brazilian isolate of the cyanobacterium Microcystis aeruginosa. J. Appl. Phycol., 6(15): 261-265. Belgium.

AZEVEDO, S. M. F. O., 1996, Current studies on toxic cyanobacteria in Brazil. REUNIÃO ANUAL DA FEDERAÇÃO DE SOCIEDADES DE BIOLOGIA EXPERIMENTAL, 12, Caxambu, MG, 40p.

BAKER, P. D. \& HUMPAGE, A. R., 1994, Toxicity associated with commonly occurring cyanobacteria in surface waters of Murray-Darling Basin, Australia. Aust. Jour. Marine and Freshwat. Res., 45(5): 773-786.

BOUVY, M., FALCÃO, D., MARINHO, M., PAGANO, M. \& MOURA, A., 2000, Ocurrence of Cylindrospermopsis (Cyanobacteria) in 39 Brazilian tropical reservoirs during the 1998 drought. Aquat. Microb. Ecol., 23(1): 13-27.

BOUVY, M., MOLICA, R., OLIVEIRA, S., MARINHO, M. \& BEKER, B., 1999, Dynamics of a toxic cyanobacterial bloom (Cylindrospermopsis raciborskii) in a shallow reservoir in the semi-arid region of Northeast Brazil. Aquatic. Microbi Ecol., 20(3): 285-297.

CARMICHAEL, W. W., 2001, Health effects of ToxinProducing Cyanobacteria: "The CyanoHABs". Human and Ecological Risk Assessment, 7(5): 1393-1407.

CHELLAPPA, N. T., 1990, Phytoplankton species composition, chlorophyll biomass, and primary productivity of Jundiaí reservoir, northeast Brazil before and after eutrophication. Acta Hydrobiologia, 32: 75-91.

CHELlAPPA, N. T., AMORIM, J. M. F., BEZERRA, T. A., CID, V. \& COSTA, I. A., 1996, Studies on the microalgae of Rio Grande do Norte: A comparison of the phytoplankton assemblages of an oligotrophic and eutrophic lakes, Brazil. Beih. Nova Hedwigia, 112(6): 513-524. Stuttgart.

CHELlAPPA, N. T., COSTA, M. A. M., MARINHO, I. R., 2000, Harmful cyanobacterial blooms from semiarid freshwater ecosystems of North-East Brazil. Australia. Aust. Soc. Limnol., 38(2): 45-49. Newsletter.

CHORUS, I. \& BARTRAM, J., 1999, Toxic Cyanobacteria in Water. E \& FN Spon, Londres, 416p.

COSTA I. A. S., CHELlAPPA, N. T. \& ARAÚJO, M. F. F., 1998, Estudo do Fitoplâncton da Barragem Engenheiro Armando Ribeiro Gonçalves, Assu-RN. Acta Limnologica Brasiliensis, 10(1): 67-80. 
COSTA, I. A. S., ARAÚJO, M. F. F. \& CHELLAPPA, N. T., 2001, Contribution to our knowledge of Cyanobacteria from Brazil. Toxin producing species from a eutrophicated reservoir of Rio Grande do Norte State. ABSTRACT BOOK, PLANKTON SIMPOSIUM, 20-22 de setembro de 2001, Espinho-Portugal, 1999p.

COSTA, I. A. S., CALAZANS, M. A. D., MEDEIROS, F. B. B., FREIRE, V. M. \& BEZERRA, R. M., 2003a, Prevalência de cianobactérias em mananciais de abastecimento público no Estado do Rio Grande do Norte. CONGRESSO BRASILEIRO DE LIMNOLOGIA, 9., Resumo.

COSTA, I. A. S., PANOSSO, R., SOUZA, S. R., MORALES, C. \& AZEVEDO, S. M. F. O., 2003b, Ocorrência de cianobactérias potencialmente e cianotoxinas em ambientes Aquáticos do Estado do Rio Grande do Norte. CONGRESSO BRASILEIRO DE LIMNOLOGIA, 9., Resumo.

COSTA, I. A. S., ARAÚJO, M. F. F. \& CHELlAPPA N. T., 2001a, Algas como bioindicadoras do nível trófico da Barragem Engenheiro Armando Ribeiro Gonçalves, AssuRN. CONGRESSO BRASILEIRO DE LIMNOLOGIA, 7., 02-06 de Setembro 2001, João Pessoa, PB, Resumo. 22p.

COSTA, I. A. S., AZEVEDO, S. M. F. O., SENNA, P. A. \& CHELlAPPA, N. T., 2001b, Ocorrência de Cianotoxinas em Florações de Cianobactérias na Barragem Engenheiro Armando Ribeiro Gonçalves (Rio Grande do Norte, Brasil). CONGRESSO BRASILEIRO DE LIMNOLOGIA, 7., 0206 de Setembro 2001-João Pessoa, PB. Resumo. p.106.

COSTA. I. A. S., Ecologia Dinâmica da Comunidade Fitoplanctônica da Barragem Engenheiro Armando Ribeiro Gonçalves, Assu/RN, 158p. Dissertação de Mestrado (Bioecologia Aquática)-Departamento de Oceanografia e Limnologia da Universidade Federal do Rio Grande do Norte, Natal, 1999.

COSTA, I. A. S., Estudos das microalgas em relação a diversidade, dominância, biomassa de clorofila $e$ produtividade primária na Barragem Engenheiro Armando Ribeiro Gonçalves, Assu/RN. Natal, RN 1996. 62p. Monografia. (Especialização em bioecologia aquática). Universidade Federal do Rio Grande do Norte. 1996.

FALCONER, I. R., 2001, Toxic Cyanobacterial bloom problems in Australian waters: risks and impacts on human health. Phycology, 40(2): 228-233.

FITZGERALD, D. J., CUNLIFFE, D. A. \& BURCH, M. D., 1999, Development of health alerts for cyanobacteria and related toxins in drinking water in South Australia. Environmental Toxicology, 14(1): 203-207.

HARADA, K. I., OHTANI, I., IWAMOTO, K., SUZUKI, M., WATANAB, M. \& TERÃO, K., 1994, Isolation of Cylindrospermopsin from a cyanobacterium, Umezakia natans and its screening method. Toxicon, 32(1): 73-84.

HAWKINS, P. R., CHANDRACENA, N. R., JONES, G. J., HUMPAGE, A. R. \& FALCONER, I. R., 1997, Isolation and toxicity of Cylindrospermopsis raciborskii from an ornamental lake. Toxicon, 35(3): 341-346.

HUSZAR, V. L. M., SILVA, L. H. S., MARINHO, M., DOMINGOS, P., \& SANT'ANNA, C. L., 2000,
Cyanoprokaryote assemblages in eight productive tropical Brazilian waters. Hydrobiol., 424(1-3): 67-77.

JOCHIMSEN, E. M., CARMICHAEL, W. W., AN, J., CARDO, D. M., COOKSON S. T., HOLMES, C. M. D., ANTUNES, M. B. D., DE MELO, D. A., LYRA, T. M., BARRETO, V. S. T., AZEVEDO S. M. F. O. \& JARVIS, W. R., 1998, Liver failure and death after exposure to microcystins at a hemodialyses center in Brazil. New England Journal of Medicine, 338(13): 873-878.

KOMÁREK, J. \& ANAGNOSTIDIS, K., 1989, Modern approach to the classification system of cyanophytes. 4 - Nostocales. Archiv für Hydrobiologie 56(82,3): 247-345, 1989. (Algological Studies, 56).

KOMÁREK, J. \& ANAGNOSTIDIS, K., 1995, Nomenclatural novelties in chroococcalean cyanoprokaryotes. Preslia, 67: 15-23. Praha.

KOMÁREK, J. \& ANAGNOSTIDIS, K., 1998, Cyanoprokariota. I. Teil Chroococcales. - In: ETTL, H., et al. (Ed). Süsswasserflora von Mitteleuropa. Jena: J.Fischer, 19(1): 1-548.

KRISHNAMURTHY, T., CARMICHAEL, W. W. \& SARVER, E. W., 1986, Toxic peptides from freshwater cyanobacteria (blue-green algae). I. Isolation, Purification and characterization of peptides from Microcystis aeruginosa and Anabaena flos-aquae. Toxicon, 24(9): 865-873.

LAGOS, N., ONODERA, H., ZAGATTO, P. A., ANDRINOLO, D., AZEVEDO, S. M. F. O. \& OSHIMA, Y., 1999, The first evidence of paralytic shellfish toxins in the freshwater cyanobacterium Cylindrospermopsis raciborskii, isolated from Brasil. Toxicon, 37(10): 1359-1373.

LAWRENCE, J. F. \& MENARD, C., 1991, Liquid chromatographic determination of paralytic shellfish poisons in shellfish after prechromatographic oxitation. Journal OAAC International, 74(6): 1006-10012.

LAWRENCE, J. F., WONG, B. \& MÉNARD, C., 1996, Determination of carbomoyl saxitoxin and its analogues in shelfish by prechromatographic oxidation and liquid chromatografic with fluorescence detection. Journal of AOAC International., 79(5): 1111-1115.

LAWRENCE, J. F., MÉNARD, C., CHARBONNEAU, C. F. \& HALL, S., 1991, A study of ten toxins associated with paralytic shellfish poison using prechromatographic oxidation and liquid chromatographic with detection fluorescence. Journal of AOAC International, 74(2): 404409.

LAWRENCE, J. F., MÉNARD, C. \& CLEROUX, C., 1995, Evaluation of prechromatographic oxidation for liquid chromatographic determination of paralytic shellfish poisons in shellfish. Journal of AOAC International., 78(2): 514-520.

LUND, J. W. G., KIPLING, LECREN, E. D., 1958, The inverted microscope method of estimating algae number and the statiscal basis of estimating by counting. Hydrobbiologia, 11(2): 143-170.

MAGAlHÃES, V. F., SOARES, R. M., AZEVEDO \& S. M. F. O., 2001, Microcystin contamination in fish from the Jacarepaguá Lagon (Rio de Janeiro, Brazil): ecological implication and human health risk. Toxicon, 39(7): 1077-1085. 
MINISTÉRIO DA SAÚDE/FUNASA: Portaria n. 1.469, de 29 de dezembro de 2000. Normas de qualidade da água para consumo humano, Brasília, 17p. Brazil.

MOLICA, R., ONODERA, H., GARCIA, C., RIVAS, M., ANDRINOLO, D., NASCIMENTO, S., MEGURO, H., OSHIMA, Y., AZEVEDO, S. \& LAGOS, N., 2002, Toxins in the freshwater cyanobacterium Cylindrospermopsis raciborskii (Cyanophyceae) isolated from Tabocas reservoir in Caruaru, Brazil, including demonstration of a new saxitoxin analogue. Phycologia, 41(6): 606-611.

NASELLI-FLORES, L., 1999, Limnological aspects of sicilian reservoirs: A comparative, Ecosystemic Approach, pp. 238311. In: J. G. Tundisi \& M. Straskabra (Eds) - Theoretical Reservoir Ecology and its Applications international Inst. of Ecology Brazilian Academy of Sciences and Backhuys Publishers.

PORFIRIO, Z., RIBEIRO, P. M., ESTEVAN, C. S., RICARDO, L. S. \& SANTANA, A. E. G., 1999, Hepatosplenomegaly caused by na extract of Cyanobacterium Microcystis aeruginosa bloom collected in the Manguaba Lagoon, Alagoas-Brazil. Revista de Microbiologia, 30(3): 278-285.
SIVONEN, K. \& JONES, G., 1999, Cyanobacterial toxins. pp. 41-111. In: I., Chorus \& J. Bartram (ed.) - Toxic Cyanobacteria in Water: a guide line to public health significance, monitoring and management. World Health Organization, London and New York.

TEIXEIRA, M. G. L. C., COSTA, M. C. N., CARVALHO, V. L. P., PEREIRA, M. S. \& HAGE, E., 1993, Epidemia de gastroenterite na área da barragem de Itaparica, Bahia. Bol. Sanit. Panam. 114(6): 502-511.

TUNDISI, J. G. \& MATSUMURA-TUNDISI, T., 1992, Eutrophication of lakes and reservoirs: a comparative analysis, case studies, perpectives, pp. 1-33. In: CordeiroMarino (Ed.) Algae and Environment: A general Approach. Brazilin Phycological Society.

YUNES, J. S., SALOMON, P. S., MATTHIENSEN, A., BEATTIE, K. A., RAGGETT, S. L. \& CODD, G. A., 1996, Blooms of cyanobacteria in the Patos Lagoon estuary, In Southern Brazil. J. Aquatic Ecossystem Health, 5(4): 223-229. 